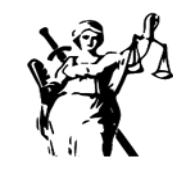

JUSTICIA

ISSN impreso 0124-7441
ISSN digital 2590-4566

\title{
International Experience of Protecting Persons in the Field of Public Administration: What Relevance of Application under Ukrainian Law?
}

\section{Experiencia internacional de personas protectoras en el ámbito de la administración pública: ¿qué relevancia tiene la aplicación según la legislación de Ucrania?}

\author{
(iD) \\ Vitalii Oleksandrovych Serohin \\ V.N. Karazin Kharkiv National University \\ v.a.seryogin@karazin.ua \\ Mark Mykolayovych Voronov \\ V.N. Karazin Kharkiv National University \\ markvoronov@karazin.ua
}

\author{
Yuliia Anatoliivna Melikhova \\ Universidad Nacional de Derecho Yaroslav Mudryi \\ yu.a.melihova@nlu.edu.ua
}

\author{
Maryna Volodymyrivna Romanenko \\ Kharkiv National University of Internal Affairs \\ marisja2008@ukr.net
}

Recibido: 9 de febrero de 2021 / Aceptado: 30 de marzo de 2021 https://doi.org/10.17081/just.26.40.4870

\begin{abstract}
Resumen
Objective: The purpose of this article is to study international experience of protecting persons in the field of public administration and determining the possibilities of its application in Ukraine. For the above, we used the analytical method and the documentary analysis to track theoretical background and to understand the current state of protecting persons in the field of public administration. Relevant issues related to the implementation of statutory methods of protecting persons in the field of public administration have been of great importance and recognition in this research platform. The experience of foreign countries in the field of protecting persons during their relations with public authorities has been studied; the possibilities of its application in Ukraine have been determined. It has been emphasized that the ability of any person to use the legally defined tools of legal protection is one of the key features of the rule of law state. It has been noted that only a country whose state power performs its direct functions on public administration without harming the rights, freedoms and legitimate interests of individuals, can be truly considered legal and democratic. Scientific points of view on the implementation of legally defined procedures for the protection of individuals in the field of public administration have been provided and compared. It has been noted that the introduction of effective methods and means of protection of persons is an extremely important aspect of state authority's activity, and especially in the context of Ukraine's European integration course.
\end{abstract}

KEYWORDS: international experience, protection of rights and legitimate interests, civil society, public administration.

\begin{abstract}
Objetivo: El propósito de este artículo es estudiar la experiencia internacional de protección de personas en el campo de la administración pública y determinar las posibilidades de su aplicación en Ucrania. Para lo anterior, utilizamos el método analítico y el análisis documental para rastrear los antecedentes teóricos y comprender el estado actual de la protección de las personas en el ámbito de la administración pública.
\end{abstract}


Los temas relevantes relacionados con la implementación de métodos legales de protección de personas en el campo de la administración pública han sido de gran importancia y reconocimiento en esta plataforma de investigación. Se ha estudiado la experiencia de países extranjeros en el campo de la protección de personas durante sus relaciones con las autoridades públicas; Se han determinado las posibilidades de su aplicación en Ucrania. Se ha enfatizado que la capacidad de cualquier persona para utilizar las herramientas de protección legal definidas legalmente es una de las características clave del estado de derecho. Se ha señalado que solo un país cuyo poder estatal ejerce sus funciones directas sobre administración pública la administración pública sin lesionar los derechos, libertades e intereses legítimos de las personas, puede ser verdaderamente considerado legal y democrático. Se han proporcionado y comparado puntos de vista científicos sobre la aplicación de procedimientos legalmente definidos para la protección de las personas en el ámbito de la administración pública. Se ha observado que la introducción de métodos y medios eficaces de protección de las personas es un aspecto extremadamente importante de la actividad de la autoridad estatal, y especialmente en el contexto del curso de integración europea de Ucrania.

PALABRAS CLAVE : experiencia internacional, protección de derechos e intereses legítimos, sociedad civil, administración pública.

Como Citar: Oleksandrovych Serohin, V., Anatoliivna Melikhova, Y., Mykolayovych Voronov, M., \& Volodymyrivna Romanenko, M. (2021). Experiencia internacional de las personas protectoras en el campo de la administración pública: ¿qué tan relevante es la aplicación de acuerdo con la ley ucraniana?. Justicia, 26(40), 3-10. https://doi.org/10.17081/just.26.40.4870

\section{Introducción}

\section{Public Administration in Ukraine a complex and common problem}

Taking into account the importance of proper protection of each subject of public and private legal relations, it should be noted that the study of this research paper constitutes one of the key elements in underlining an objective understanding of the processes associated with the functioning of the rule of law state in adequate consideration. Proper treatment with each of the subjects of legal relations significantly increases their joint interaction, and therefore directly affects the quality of daily functioning of the entire state system of the country. According to the historically formed types of development of social legal relations that took place in the past, and some of which were transformed till the present day, the greatest success in the field of economic growth was achieved by those state entities that properly protected the rights, freedoms and legitimate interests of individuals.

In the context of the above, supports the point of view of M. A. Akhmedshaeva (2020) and others that:

«Processes of formation of the newest legislation on administrative responsibility in the country remains an actual problem which must receive due scientific assessment without which placing a definition which will underpin the prospects of development of this legislation, in our opinion, is represented rather problematic. These prospects are associated with the search of the most optimal forms of administrative and jurisdictional protection of new public relations from illegal encroachments, requiring the account of experience in the legal regulation of administrative responsibility. The solution of these problems seems to be possible only on the basis of in-depth study and theoretical systematization of the current administrative and tort legislation in the country, identification of contradictions in its development and modeling of its further development». 


\section{Understanding the Stakes and Rationale of the Subject Matter}

It is worthy of note that, in accordance with the high relevance of the problems and issues that are the main content of this article, their scientific and legal analysis and research constitutes a brave sphere of interests of a large number of scholars in the legal sphere. Therefore, the domestic society has the opportunity to get acquainted with a large number of scientific papers and publications published in different periods of time. In particular, it should be noted that the most authoritative of such works are the papers of such scholars as: V. D. Bakumenko, T. Yu. Vytko, O. Krupchan, M. M. Potip, T. Tarasenko, A. O. Tkachenko, N. V. Yaniuk and others. This involves the establishment of the system of legal means, as well as the definition of international experience on their implementation into the practice of public authorities.

\section{The Necessity and Essence of Public Administration in Ukraine}

In most cases, there must be an absolute awareness of the fact that citizens and enterprises can freely and unhindered exercise their rights, freedoms and legitimate interests for their effective activity in any sphere of public life. Without adherence to these basic elements of economic and social efficiency, no state will be able to ensure its effective functioning. In order to ensure proper protection of the rights and freedoms of every person and citizen, Article 3 is of utmost importance. The Constitution of Ukraine declares: Human rights and freedoms and their guarantees determine the content and orientation of state activity. The state is accountable to a human being for its activities.

V. Averianov (2004, p. 584) rightly emphasizes that the uniqueness of administrative and legal relations, especially the activities of subjects of public administration, is that they are a unique public legal entity, whose main task is to protect the rights, freedoms and legitimate interests of individuals. The scholar notes that the establishment of legal norms regulating administrative and legal relations does not exclude cases of their violation by public administration agencies. In order to prevent such violations, according to the expert, it is necessary to take certain administrative and legal measures to protect the rights, freedoms and legitimate interests of individuals and legal entities. Administrative and legal protection of individuals rights is a reliable guarantee of rapid, effective and objective transformation of the general concept of "protection of human rights" from rhetorical to real.

In order to provide a proper scientific and legal assessment of all views and interpretations lets, first of all, define the concept of an individual. According to V. Dubichynskyi (2018, p. 527), an individual is a person who acts personally and informally. An important right of an individual is the right to own, use and dispose of his property private, as a form of appropriation, when the means of production and products of labor belong to certain persons in accordance with the law.

An individual, from the point of view of the theory of public administration, should be considered as an object of public administration, having both positive and negative managerial influence of the subject of public administration. In this case, the individual is recognized as obliged to comply with the legal requirements of the subjects of implementing public administration.

It is considered that an individual has the appropriate, inherent ability within administrative and tort relations to be the subject of these legal relations. Only in case of a specific violation of the prohibitions of administrative law, an individual will be able to become the subject of an administrative offense. It follows that in case of failure of a certain person to act, which would be defined in accordance with the current administrative law as administrative violations, he cannot be considered a subject of administrative and tort relations (Halunko, et al., 2018, p. 446). 
The majority of jurists tend to distinguish a number of some characteristic features of an individual in the system of implementing public management and administration. According to them, a person, who acts personally, informally and who is not an official and does not perform the executive functions delegated to him by the state is recognized as an individual.

Another feature of an individual is his leading role among other subjects of public legal relations. It is primarily due to the fact that it is to fully satisfy the rights, freedoms and legitimate interests of non-governmental individuals and legal entities that are the absolute majority of citizens of any country, and carry out the activities of public authorities in the sphere of public administration.

In the final part of the process of determining the characteristics of an individual, it should be noted that it should be perceived in the system of administrative law both as a subject of administrative and legal relations, as an object of public administration and, at the same time, as a subject of administrative and tort relations.

A significant change, which has recently become more pronounced, is the radical reorientation of the domestic state system from one that dominates on persons and oppresses them, to one that is really able to perform the service function as the most important essence of its purpose. This is to adhere to the principle of "serving one's people, which is already common for the developed countries of Western Europe and North America.

At the same time, the main accents of the characteristics of administrative law are shifting from purely administrative to law enforcement and advocacy ones. Such areas of ensuring the realization of the rights of individuals and citizens as their effective protection and protection in case of violation are becoming important. In turn, this means that legal procedure, as well as all currently available conditions and procedures for the protection of the rights and freedoms require a clear regulation (Stetsenko, 2011, p. 258).

R. S. Melnyk and V. M. Kuzmyshyn (2014, p. 376) rightly noted that it is primarily necessary to establish an effective mechanism for administrative appeal by private individuals of illegal actions against them from the part of public authorities. in order to properly build checks and balances system within the state system of the country, which would have the ability to reliably and timely protect the rights, freedoms and interests of each individual, as well as successfully maintain such system. Appealing against decisions, actions or omission of public authorities, local self-government agencies, their officials is "an important guarantee of the implementation of the constitutional principle of state responsibility to a human being for its activities". The implementation of this right of citizens is a huge asset of democracy and civil society, because citizens and administration in such a society are recognized as equal parties.

Not least of all, actions and methods in regard to protect the rights, freedoms and legitimate interests of individuals are carried out through the active use of high-tech devices. In particular, researchers suggest that they should be understood as methods and tools that provide an appropriate level of protecting certain personal information about a person. Means of security and protection of information related to personal data of individuals or related to their professional activities are extremely important elements of the state protection system. One of such elements of maintaining information security during the implementation of the direct responsibilities by state agencies (institutions and organizations) in the field of public administration is the gradual replacement of paperwork in public office activities on computer databases (Tsyhanov, 2016, p. 10). Therefore, the logical continuation of this reform is the almost complete replacement of paper archives with secure server rooms, which have the ability to store large amounts of 
information about individuals. There is also a large-scale transfer of all government agencies that are part of the process of carrying out public administration into the use of digital media (Hrytsenko, et al. 2017, p. 376).

According to Ya. Yu. Kondratiev (2004, p. 236), information technology security is a complex problem, which includes legal regulation of IT use, improvement of technologies for their development, certification systems development, provision of appropriate organizational and technical conditions of operation. Solution of this problem requires significant costs, so the priority task is to balance the level of required security and the costs for maintaining it. Administrative means are integral part of information protection, their importance is due to the fact that they are available and able to supplement legislative norms where it is required, and the peculiarity is that they mostly provide the application of other types of protection (technical, software) and only in this case guarantee sufficiently reliable protection.

The scientific literature emphasizes that the availability of a number of modern and powerful electronic systems of protection, storage and processing of information within state authorities together with the existence of clear and effective legislation regulating the processes of applying these electronic systems, is an extremely effective factor in protection of the rights, freedoms and legitimate interests of individuals (Nikolaiuk, et al. 2006, p. 319).

Numerous recommendations addressed to the governments of the Member States of the Council of Europe usually state that there must also be an effective mechanism for compensating individuals for moral or material damage caused to them by public authorities together with the existence in the state of certain norms and means that can provide adequate protection to individuals in the performance of the direct duties by public administration subjects.

Besides clarifying the fact of doing harm to an individual by public administration agencies, as well as determining the amount of compensation, the very procedure of such compensation is important for the protection of the rights, freedoms and interests. In this case, it is possible to apply various procedures for the compensation of damage caused by public administration agencies and institutions that carry out public administration. In this context, Recommendation R (84) 15 of the Committee of Ministers of the Council of Europe to Member States regarding public and legal responsibility for the caused damage, emphasizes that the understanding of the types and sequence of applying such procedures is important for the successful protection or restoration of the rights, freedoms and interests. The sequence of applying the procedures for the compensation of damage caused by the public administration agencies depends on the actual circumstances of the caused damage and its compensation.

Representatives of national legal communities note that the political elite and society while building a quality system in the state that would carry out effective public administration, should act only on the basis of proper observance of fundamental values of a man and citizen, thus protecting the rights, freedoms and legitimate interests. not so much the state as inclusive of each of the individuals. Therefore, according to the quite correct statement of O. V. Musa (2014, p. 117), the rights and freedoms of a man and citizen are the basis of the legal norms in the state. It follows that the enshrinement of human and civil rights and freedoms in the Constitution and legislation imposes both certain amount of opportunities (powers) to realize their legitimate interests and responsibilities in various types of legal relations on all participants in the legal relations. Thus, the fundamental nature of human and civil rights and freedoms, their philosophical and ideological content and social significance play a significant role in establishing the system of relationships between the holders of such rights and freedoms and other participants in legal relations. In this context, it should be added that while creating a fundamentally new legislative regulation of the activities of agencies 
and institutions involved in service activities of public administration, it is necessary to establish a clear framework within the relevant legislative acts, which would nullify the ability of public authorities to narrow the rights and freedoms of individuals and legal entities.

The experience of the Federal Republic of Germany is among the examples of the countries with a high level of protection of individuals in the field of public management and administration. According to Professor 0 . Buhler the subjective public rights in this country include all the rights of individuals recognized by law, regardless of the level and hierarchy of legal norms. The case law of this state is also based on the theory of "protective norm".

\section{Placing and Examining the Rule of Law in Public Administration Exchange}

The Law on Administrative Courts of the Federal Republic of Germany establishes a double condition for the annulment of an administrative act and a possible decision on appeal: its illegality and consequently the violation of the plaintiff's rights (Kozyrin \& Shtatina, 2003, p. 312-327). However, in order to recognize the existence of an individual's subjective public right, it is not necessary that the legal norm, which contains this right, includes a clearly defined requirement. The only thing that is fundamentally important is the condition that the legal norm, in accordance with the objective will of the legislator, should serve not only as the general, but also as the individual (and it is mandatory) interests of individuals. Equality of citizens and the state as subjects of public rights and responsibilities is expressed in the comity of these rights and responsibilities.

Analyzing the above allegations, it can be noted that Ukraine, in accordance with the current norms of domestic law, has a division of the rights and legitimate interests of individuals into absolute and relative. The criterion for such a division is, first of all, the degree of possibility of realizing these rights and legitimate interests; secondly, the possibility to restrict a certain right of an individual in the manner and on the grounds provided by law.

\section{Questioning the Right and Standard in Possessing an Effective Administrative Platform}

In most rights emanating from administrative functioning, when implementating such right it is protane that such are considered absolute, and its realization in most circumstances depends on the will of the citizens. A pertinent and fundamental is that as to the, right to participate in the administration of state affairs both directly and through the representatives. The tendency to be admitted to secondary schools, personal freedom and inviolability, address personally, as well as to send individual and collective claims to state agencies and local self-governments; to the states compensation for the damage caused by illegal actions (or omission) of public administration entities or their officials.

It is germaine to note that these rights postulated are relative, since implementation depends both on the will of individuals, and on the availability of actual opportunities for their implementation in this place and at this time. They include, for example, the right of citizens to enter a higher educational institution; to drive a vehicle. Thus, the success of the implementation of certain rights in this case directly depends on the state of health, the results of exams.

A lot of relative rights while achieving succeeds in the economic and socio-cultural spheres, may become absolute, but not in all cases. The realization of relative rights often depends on the personal qualities of an individual (health status, professional education, etc.) or on the time (priority) of satisfying a legitimate request (for example, installation of a telephone, provision of living space) (lierusalimova, 2006, 
p. 205). The same principle is used to define and classify the responsibilities of individuals. The absolute responsibilities in this case are those imposed on an individual in the field of public administration, and the implementation of which does not depend on any circumstances, since it is determined by the current legislation. Accordingly, relative responsibilities largely depend on the will of a particular individual.

\section{Conclusions}

The introduction of effective methods and means of protecting individuals during the processes related to the implementation of public administration activities by state agencies (institutions and organizations) is extremely important for the successful introduction of a human-centered model of relations between public administration agencies and citizens. Such measures will significantly strengthen the national state system, making it much more efficient. It will be possible because each of the subjects of legal relations, understanding the fact that he is safe (under the protection of law and public authorities), is able to act freely and productively, which, in turn, can strengthen the country and its economy.

\section{bibliographic references}

Akhmedshaeva, M.A. et al. (2020). The Process of Reforming the System of State Administration and Administrative Reform in Uzbekistan. Journal of Advanced Research in Law and Economics, Volume XI, Spring, 2(48): 273-278. DOI: 10.14505/jarle.v11.2(48).01.

Averianov V. B. (chief) (2004). Administrative Law of Ukraine. Academic course: textbook: in 2 volumes: Vol. 1. General part / Kyiv: Yurydychna dumka.

Dubichinskyi, V. V. (2018). Administrative Law: manual for Universities. Kyiv: Pravova yednist.

Halunko, V., Dikhtiievskyi, P., Kuzmenko, O. et al. (2018) Administrative Law of Ukraine. Full course: textbook / Kherson: OLDI-PLIUS.

Hrytsenko, I., Melnyk, R., Pukhtetska, A. et al. (2017). General Administrative Law: textbook. Kyiv: Yurinkom Inter.

lierusalimova, I. O. (2006). Mechanism of Administrative and Legal Guaranteeing of Human and Civil Rights and Freedoms: PhD in Law dissertation: 12.00.07. Kyiv.

Kondratiev, Ya. Yu. (edit.) (2004). Detection and Investigation of Crimes Committed in the Field of Information Technologies: scientific and practical manual. Kyiv.

Kozyrin, A. N., \& Shtatina M.A.(2003). Administrative Law of Foreign Countries: textbook. M.

Melnyk, R. S., \& Bevzenko, V. M. (2014). General Administrative Law: manual / Kyiv: Vaite.

Muza, O. V. (2014). Administrative and Legal Mechanism of Protecting the Rights, Freedoms and Interests of Individuals and Legal Entities in Ukraine. Naukovi zapysky Instytutu zakonodavstva Verkhovnoi Rady Ukrainy. No. 6, 32-36.

Nikolaiuk, S. I., Nykyforchuk, D. I., Tomma, R. P., \& Barko, V. I. (2006). Crime Combating in the Field of Intellectual Property. Kyiv. NAVS.

Recommendation R (84) 15 of the Committee of Ministers of the Council of Europe to Member States on public liability for damage, adopted by the Committee of Ministers of the Council of Europe on 11 September 1984 at the 375th meeting of the Ministers Deputies. https://zakon.rada.gov.ua/laws/ show/994_126\#Text 
Stetsenko, S. (2011). Administrative Law of Ukraine: manual. Kyiv: Atika.

Tsyhanov, O. (2016). Administrative Appeal as Important Means of Ensuring Legality while Providing Administrative Services in the Field of Law Enforcement Activity. Visnyk Luhanskoho derzhavnoho universytetu vnutrishnikh sprav imeni E.O. Didorenko. No. 1, 207-216. 